\title{
SELECTION PROCESS FOR THE TENDER WINNER OF STORAGE TANK CONSTRUCTION BASED ON AHP IN MARKETING OPERATION REGION V PERTAMINA
}

\author{
Gadri Bachmid $^{1}$, Udisubakti Ciptomulyono ${ }^{2}$, Endah Angreni $^{3}$ \\ ${ }^{1,2,3}$ Management of Technology, Sepuluh Nopember Institute of Technology, Surabaya Indonesia \\ gadri21@gmail.com
}

\begin{abstract}
Evaluation on the selection of winning contractors of tenders requires an assessment of the process as the most important element. That is because there are so many criteria taken into account by their clients. One of the contractors' service clients in Indonesia is the Technical Services Region V Pertamina who is responsible for any undertakings of investment projects in the area of East Java, Bali and Nusa Tenggara. However, the potential problems occur frequently are construction failure and belated project which is underway for years past the expected time of construction work. The construction phase is a direct indication of the contractor selection process. Poor construction phase cannot be separated from the under privilege tendering process. As a result of the bad contractor selection process, the projects are undertaken by the unqualified and inexperienced contractors. This research is expected to provide solutions to optimize the cost and quality of contractors. Design of this research is descriptive, with the case study method. The approach taken is a mixed research (mix methodology) that combines qualitative and quantitative approaches. The data in this study were collected through questionnaires. Method of data analysis used in this study uses Analytical Hierarchy Process (AHP). Results revealed that the method can be used for predicting overall relative strength of each candidate. This application can also be developed to the wider scope of work and qualification of contractors.
\end{abstract}

Keywords: Tender, Storage Tank Construction, Analytical Hierarchy Process (AHP)

\section{INTRODUCTION}

The common problems occuring in storage tank construction especially with big qualification are a failure construction and belated project which is underway for many - years past expected time of construction work. For example, in the last five years there has been a 6 cases of construction failures and projects which are not able to be taken over because they stray away from the plan project in Region $\mathrm{V}$ Pertamina Marketing Operation. The construction phase is a direct indication of the contractor selection process. Poor construction phase cannot be separated from the bad tendering process. As a result of the bad contractor selection process, the projects are won and undertaken by the unqualified and inexperienced constractors, which are not able to undertake projects as according to expected standard. In general, tendering process of construction project uses a single stage two covers. Then, the process is evaluated to apply a scoring method by selecting a specific evaluation form using the lowest prices, as explained in the previous section. The lowest price is considered to be the most objective form and to avoid the risk of unidentified subjectivity, besides the ease of audit. However, the low price indirectly causes the emergence of the risk of the low work quality and undertaking of projects take longer time than the initial plan. This can be partly mitigated by determining in great detail of requirement specifications on the bill of quantity and doing tight supervision on the specifications of items on the planned projects. However, the unqualified contractors may try to reduce cost in the implementation methods by using fewer workers even inexperienced. The potential problems also often lie on badly financial and organized management applied by the contractors which causes no realization of on-time labour payment, especially skilled workers. This causes projects undertaken are not in according to engineering design, belated projects undertaking, even contract break-up. Because tendering process involves a lot of efforts and Pertamina, on the other side, must still conduct strict selection for contract winner of the tender due to the importance of this phase previously explained, it requires a simply practical application which is able to convert a scientific process of selecting contractors based on the existing performance data to information-technology based on practical systems without swerve from the rule of procurement decree of goods and services. This information system will take a role in the process of comparing bids from contractors. Although Pertamina has had a policy related to the procurement of goods and services through a technical selection process, HSE Plan and prices, the fact that required technical documents and HSE plan can be easily passed when contractors often perform similar job analysis. This system is expected to be able to solve the problems of the tendering that takes place in the Technical Services Region V Pertamina. 


\section{METHODOLOGY}

AHP Method developed by Thomas. L. Saaty around 1970 has been studied and developed by researchers since then. The significant advantage of this method is the consistence test on the sequential hierarchy which is user-friendly to make decision from the relatively complex criteria. The following steps will be done in this method:

1. Define the problem and determine the desired solution and draw up a hierarchy of the problems faced. At this stage, users will attempt to determine the problem distinctly, in detail and understadably. Then, it will set the expected solution suited for handling the problems that occur. It may result one solution or more, then the solutions will be developed in the next stage

2. Make a hierarchical structure by setting a general objective, as the whole system target. Previously, arrangement of main objectives will be drawn up as toplevel where lower-level hierarchy will be drawn up next, which contains suitable criteria for considering or conducting the assessment alternatively and determining the alternatives.

3. Make a comparison matrix that describes the relative contribusive or influence of each element on the objectives or criteria which are one-level higher. The matrix used is simple, has a strong position on the framework of consistency, obtains other information that may be required with all possible comparisons and are able to analyze the whole sensitivity of priorities for consideration change. Matrix Approach reflects the dual aspect in the priority that dominates and be dominated.

4. Define correlative comparison in order to obtain total assessment which is $n x[(n-1) / 2] . n$ is the number of compared elements. The results of the comparison of each element will be in number from 1 to 9 and shows a comparison of comparison degree of an element. If an element in the matrix is compared to the element itself, the results of the comparison will be presented by number 1 . Next, the results of the comparison is filled in cells corresponding to the compared elements. The following correlative comparison scale according to the intensity of interest introduced by Saaty (1987) is:

a. Both elements are equally important, and the two elements have equally great effect. b. An element is a bit more important than the other elements, so that the experience and judgment slightly favor one element than any otherelement. c. An element is more important than any other elements, so that tenacious experience and judgement can support one element than any other element. d. One more absolute element has an interest than any other element, so that the strong element is supported and more dominant in practice. e. One more absolute element than any other element. f. 2,4,6,8: Values/ scores between two adjacent values considerations.

5. Calculate eigen values and conduct consistency test. If the test results show inconsistency, data can be recollected

6. Repeat the steps 3,4 and 5 at all levels of the hierarchy
7. Calculate the eigen vectors of each correlation comparison matrix which is the weight of each element for determining the elements priority from the lowest hierarchy level to the objectives achievement. Calculation is done by adding up the value of each column of the matrix, dividing each value of column by the total column to obtain a matrix normalization and dividing the number of elements to obtain the average.

8. Check the consistency of the hierarchy. Here are the steps to measure consistency:

a. Multiply every value of the first coloumn by the first relative priority of element, and multiply the value of the second coloumn by the second relative priority of element and so on.

b. sum every row.

c. Divide the result of the sum of row by the relative priority element, then the result is summed.

d. Divide the result of the sum by the sum of element in order to obtain lambda max $\left(\lambda_{\max }\right)$.

9. Calculate the value of Consistensy Index (CI). Here is the formula:

$$
\begin{array}{lrl} 
& C I=\left(\lambda_{\max }-n\right) /(n-1) \\
\mathrm{CI} & : \text { Consistensy Index } \\
\mathrm{N} & : \text { Number of element }
\end{array}
$$

10. Calculate the value of Consistency Ratio (CR). Here is the formula:

$$
\begin{array}{ll} 
& C R=\frac{C I}{R I} \\
\mathrm{CR} & : \text { Consistensy ratio } \\
\mathrm{CI} & : \text { Consistensy Index } \\
\mathrm{RI} & : \text { Random Index }
\end{array}
$$

11. Check the hierarchy of Consistency

The data are defined consistent if the value of $\mathrm{CR}<$

1. The process of consistency assessment is applied to the all hierarchy.

\section{CONTRACTOR PERFORMANCE CRITERIA}

These are the following performance criteria used to assess contractors (Anagnostopoulos \& Vavatsikos, 2006):

1. Financial Performance

These are the following indicators used to assess variable of Financial Performance.

a. The net wealth in latest year

b. The total debt in latest year

2. Technical Performance

Technical Performance is divided into 2 assessments, that is resource and experience. Here are the following indicators used to assess variable of Technical Performance:

a. Resources

- The completeness of storage tank construction equipment

- $\quad$ The number of fixed workers owned by contractors

- Annual budget used for training programs

b. Experience

- Experience of contractors in general construction

- Experience of contractors in managing storage tank construction

- The numbers of contracts of storage tank construction achieved at PT. Pertamina (Persero) 
3. Health \& Safety Policy

These are the following indicators used to assess variable of Health \& Safety Policy:

a. The level of discipline on safety policy applied in practice

b. The number of well-trained workers for safety training

4. Past Performance

These are the following indicators used to assess variable of Past Performance: a. on-schedule project completion as according to the contract

b. on-cost project completion as according to the contract

c. Realization of project as according to the prior plan design

\section{RESULT AND DISCUSSION}

Hierarchy arrangement will be used to determine hierarchy level and determine any relation between sub criteria as follows:

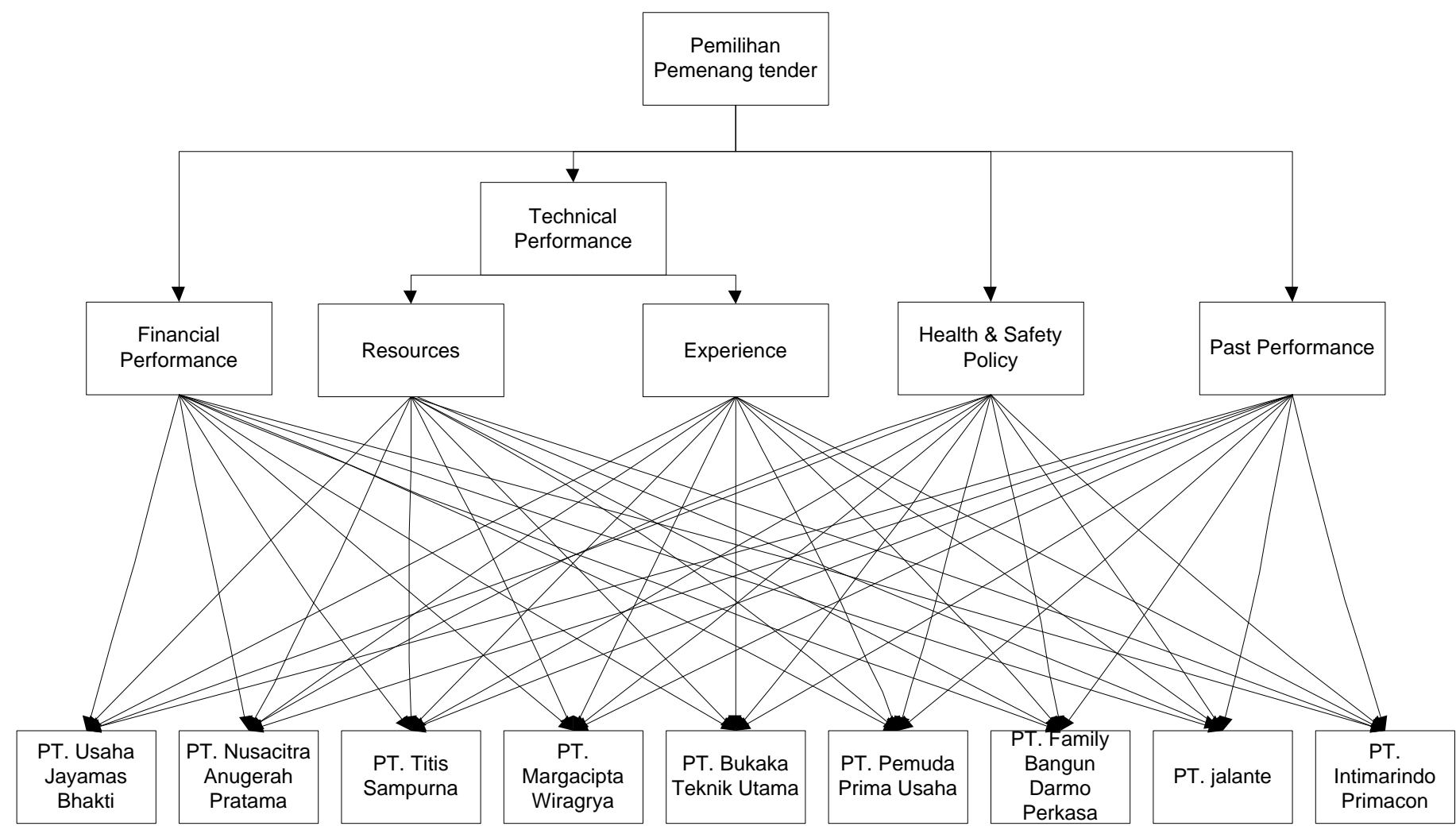

Fig. 1 Hierarchy Structure of Contractor Selection in Technical Services Region V Pertamina

Based on AHP method, this model has $\mathrm{n}=9$ and $\mathrm{RI}=1,45$. After manual calculation performed, it has been proven that every pairwise matrix for this model has consistency index $(\mathrm{CR})<0,1$ thus regard as consistent. The result of this research is a Contractor Performance Index (IPK) which is able to be used for comparison instrument in tender bidding process as follows:

Table 1. Contractor Overall Priority Index

\begin{tabular}{|c|c|c|c|c|c|c|c|c|c|c|c|c|c|c|c|c|}
\hline & $\begin{array}{c}\text { Nilai } \\
\text { kekayaan } \\
\text { bersih } \\
\end{array}$ & $\begin{array}{c}\text { Total } \\
\text { Hutang }\end{array}$ & $\begin{array}{l}\text { Resources } \\
\text { (Peralatan) }\end{array}$ & $\begin{array}{r}\text { Resources } \\
\text { (Pekerja) }\end{array}$ & $\begin{array}{c}\text { Resources } \\
\text { (Biaya) }\end{array}$ & $\begin{array}{l}\text { Experience } \\
\text { (Kontruksi) }\end{array}$ & $\begin{array}{c}\text { Experience } \\
\text { (Tangki) }\end{array}$ & \begin{tabular}{|c|} 
Experience \\
(Jumlah \\
Tangki) \\
\end{tabular} & \begin{tabular}{|c|} 
Tingkat \\
kepatuha \\
$\mathrm{n}$ \\
\end{tabular} & $\begin{array}{c}\text { Jumlah } \\
\text { Pekerja } \\
\text { Safety } \\
\end{array}$ & $\begin{array}{c}\text { Realisasi } \\
\text { Zero } \\
\text { Accident }\end{array}$ & Schedule & Cost & $\begin{array}{l}\text { Realisasi } \\
\text { Pekerjaan }\end{array}$ & \begin{tabular}{|l|} 
Overall \\
Priorty
\end{tabular} & Prioritas \\
\hline & 0,750 & 0,250 & 0,669 & 0,243 & 0,088 & 0,724 & 0,193 & 0,083 & 0,643 & 0,074 & 0,283 & 0,633 & 0,260 & 0,106 & & \\
\hline PT Usaha Jayamas & 0,149 & 0,036 & 0,055 & 0,191 & 0,018 & 0,180 & 0,175 & 0,151 & 0,234 & 0,148 & 0,206 & 0,158 & 0,047 & 0,034 & 0,144 & II \\
\hline PT Nusacitra Anugrah & 0,115 & 0,095 & 0,305 & 0,080 & 0,252 & 0,050 & 0,118 & 0,126 & 0,083 & 0,227 & 0,079 & 0,053 & 0,131 & 0,152 & 0,120 & IV \\
\hline PT Titis Sampurna & 0,036 & 0,185 & 0,022 & 0,033 & 0,117 & 0,050 & 0,031 & 0,019 & 0,083 & 0,097 & 0,206 & 0,053 & 0,037 & 0,019 & 0,063 & IX \\
\hline PT Margacipta & 0,030 & 0,110 & 0,210 & 0,138 & 0,085 & 0,087 & 0,175 & 0,019 & 0,083 & 0,148 & 0,079 & 0,053 & 0,131 & 0,152 & 0,100 & $\mathrm{VI}$ \\
\hline PT Bukaka Teknik & 0,318 & 0,016 & 0,091 & 0,309 & 0,158 & 0,229 & 0,091 & 0,227 & 0,083 & 0,099 & 0,079 & 0,158 & 0,131 & 0,152 & 0,179 & I \\
\hline PT Pemuda Prima & 0,060 & 0,055 & 0,109 & 0,080 & 0,252 & 0,026 & 0,069 & 0,032 & 0,032 & 0,057 & 0,033 & 0,158 & 0,131 & 0,152 & \begin{tabular}{|l|}
0,079 \\
\end{tabular} & VIII \\
\hline PT Family Bangun & 0,065 & 0,159 & 0,066 & 0,030 & 0,037 & 0,106 & 0,069 & 0,050 & 0,234 & 0,064 & 0,206 & 0,053 & 0,131 & 0,034 & 0,105 & $\mathrm{~V}$ \\
\hline PT Jalante & 0,057 & 0,127 & 0,039 & 0,080 & 0,043 & 0,050 & 0,031 & 0,040 & 0,083 & 0,070 & 0,079 & 0,158 & 0,131 & 0,152 & 0,080 & VII \\
\hline PT Intimarindo & 0,172 & 0,218 & 0,103 & 0,055 & 0,025 & 0,143 & 0,262 & 0,201 & 0,083 & 0,103 & 0,033 & 0,158 & 0,131 & 0,152 & \begin{tabular}{|l|}
0,131 \\
\end{tabular} & III \\
\hline \multicolumn{15}{|c|}{ SUM } & 1,000 & \\
\hline
\end{tabular}


Those results can be used as a reference for further decision making process, for example it can be used with weighted average method that consists either tender price and conteractor performance index (IPK). Sensitivity analysis can also be applied to determine the most sensitive criteria and the most robust criteria. Sensitive criteria means that criteria can change overall index significantly that in the end can also reset the priority order. Contractors and owners of the project altogether shall give highest attention for these criteria, since it can give huge impact that lead to project failure. While, robust criteria does not have the same trait as sensitive criteria.

\section{CONCLUSION}

Analytical hierarchy process is proven to be best suited for any calculation regarding contractor relative strength to each other or in this paper regard as contractor performance index (IPK). These results can be used as a reference for further decision making process or moreover establish some IT based information system for ease of user application. Sensitivity analysis can also be applied for further analysis so contractors and owners of the project will be able to determine which criteria is the most sensitive that has the highest impact for the project and which criteria is the most robust that almost does not have any significance in contractor's priority alteration.

\section{REFERENCES}

[1] Ahmad, Fadhilah., M. Yazid M Saman, Fatma Susilawati Mohammad, Zarina Mohamad dan Wan Suryani Wan Awang. (2014). Group Decision Support System Based on Enhanced AHP for Tender Evaluation.

[2] Ahmad, Fadhilah., M. Yazid M Saman, Fatma Susilawati Mohammad, Zarina Mohamad dan Wan Suryani Wan Awang. (2014). Group Decision Support System Based on Enhanced AHP for Tender Evaluation.

[3] Alias, Ros Haslida., Noor Maizura Mohamad Noor, Ali Selamat, Md Yazid Mohd Saman, Mohd Lazim Abdullah. (2012). Decision Making Model for Electronic Tender Evaluation (eTE) Using Fuzzy AHP with Extent Analysis Method.

[4] Al-Tmeemy, Samiaah M. Hassen M., Prof. Dr. Hamzah Abdul- Rahman, Associate Prof. Dr. Zakaria Harun. (2012). Evaluation and Selection of Construction Contractors Based on Analytic Hierarchy Process (AHP).

[5] Anagnostopoulos, K. P, Vavatsikos, A. P. (2006). An AHP Model for Construction Contractor Prequalification.

[6] Arikunto S, 2006.Prosedur Penelitian Suatu Pendekatan Praktik, Ed Revisi VI,

[7] Batarius, P. (2013). Analisis Metode AHP dalam Penentuan Prestasi Gabungan Kelompok Tani. Seminar Nasional Teknologi Informasi dan Komunikasi 2013 (SENTIKA 2013).

[8] Budiarto, E., \& Anggraeni, D. (2003). Pengantar Epidemologi. Jakarta: Penerbit Buku Kedokteran EGC.
[9] Cheng, Eddie W.L., Heng Li. (2004). Contractor Selection Using The Analytic Network Process.

[10] Churchill, G. A. (2005). Dasar-dasar Riset Pemasaran, Edisi 4, Jilid 1. Jakarta: Erlangga.

[11]Eriyanto. (2007). Teknik Sampling. Yogyakarta: PT LKiS Pelangi Aksara.

[12] Gayatri, Vyas., Chetan, Misal. (2013). Comparative Study of Different Multi-criteria Decision-making Methods. International Journal on Advanced Computer Theory and Engineering (IJACTE), ISSN: 2319-2526, Volume 2, Issue 4, 2013.

[13] Giannikis, Vyron. (2011). Value Based Tendering : A Model for the Contractor to Provide Added Value on Bid Documentation and Increase the Chances of Winning the Tender.

[14] Gulo, W. (2010). Metodologi Penelitian. Jakarta: Grasindo.

[15] Hatush, Zedan., Skitmore, Martin. (1997). Contractor Selection Using Multicriteria Utility Theory : An Additive Model.

[16]Herjanto, E. (2008). Sains Manajemen Analisis Kuantitatif Untuk Pengambilan Keputusan. Jakarta: Grasindo.

[17] Honggowibowo, A. S. (2010). Implementasi Metode Analytical Herarchy Process Untuk Pengambilan Keputusan Pemilihan Foto Berdasarkan Tujuan Perolehan Foto. Angkasa Volume 2, Nomor 1, April 2010.

[18] Ishizaka, Alessio., Labib, Ashraf. (2009). Analytic Hierarchy Process and Expert Choice : Benefits and Limitations.

[19] Kerlinger, Fred N (1979). Behavioral Research : A Conceptual Approach, New York: Holt, Rinehart \& Winston.

[20] Kurniady, R. K., \& Munggana, W. (2013). Sistem Perbandingan dan Penyediaan Informasi Kendaraan Mobil dengan Metode AHP. ULTIMA InfoSys, Vol IV, No. 1 Juni 2013 ISSN 2085-4579.

[21] Laudon, K. C., \& Laudon, J. P. (2008). Sistem Informasi Manajemen, Edisi 10 Buku 2. Jakarta: Salemba Empat. 